\title{
Nasal Cavity and Ethmoid Sinus Cancer Pathologic Regional Lymph Nodes TNM Finding $v 7$
}

National Cancer Institute

\section{Source}

National Cancer Institute. Nasal Cavity and Ethmoid Sinus Cancer Pathologic Regional

Lymph Nodes TNM Finding v7. NCI Thesaurus. Code C89110.

A pathologic finding about one or more characteristics of nasal cavity and ethmoid sinus cancer, following the rules of the TNM AJCC V7 classification system as they pertain to staging of regional lymph nodes. 